\title{
PENGGUNAAN MEDIA YOUTUBE UNTUK MENINGKATKAN PEMAHAMAN MAHASISWA PGSD PADA MATERI SIMETRI DI STKIP MUHAMMADIYAH OKU TIMUR
}

\author{
Mewa Zabeta ${ }^{1}$ \\ STKIP Muhammadiyah OKU Timur ${ }^{1}$ \\ zmewa@yahoo.co.id
}

\begin{abstract}
ABSTRAK
Penelitian ini bertujuan untuk meningkatkan pemahaman mahasiswa PGSD di STKIP Muhammadiyah OKU Timur pada materi simetri melalui penggunakan media youtube. Jenis penelitian ini adalah Penelitian Tindakan Kelas (PTK). Subyek penelitian ini adalah mahasiswa PGSD di STKIP Muhammadiya OKU Timur angkatan pertama pada tahun 2019-2020. Metode pengumpulan data dilakukan melalui metode observasi, tes dan dokumentasi. Teknik analisis data menggunakan metode yang meliputi pengumpulan data, penyajian data, dan penarikan kesimpulan. Hasil penelitian ini menunjukkan adanya peningkatan pemahaman mahasiswa mengenai konsep dasat simetri pada mata kuliah geometri dan pengukuran pada saat semester genap. hal ini dapat dilihat melalui nilai tes yang dihasilkan pada tes awal pembelajaran nilai tertinggi 70 dan nilai terendah 35 dengan rata-rata nilai 48 dan rentan nilai 35, pada siklus I nilai kuis 1, nilai tertinggi 72 dan nilai terendah 40 dengan rata-rata nilai 55 dan rentan nilai 32 sedangkan siklus II, nilai tertinggi 95 dan nilai terendah 65 dengan rata-rata nilai 76 dan rentan nilai 30. Kesimpulan penelitian ini adalah bahwa penggunakan media youtube dapat meningkatkan pemahaman mahasiswa PGSD di STKIP Muhammadiyah OKU Timur pada materi simetri.
\end{abstract}

Kata kunci :

Peningkatan; Media; Simetri; Youtube;Tindakan Kelas.

\section{ABSTRACT}

This study aims to improve the understanding of PGSD students at STKIP Muhammadiyah OKU Timur on symmetry material through the use of youtube media. This type of research is Classroom Action Research (PTK). The subjects of this study were the first batch of PGSD students at STKIP Muhammadiyah OKU Timur in 2019-2020. Methods of data collection are carried out through the method of observation, tests and documentation. Data analysis techniques using methods that include data collection, data presentation, and drawing conclusions. The results of this study indicate an increase in students' understanding of the concept of symmetry in geometry and measurement subjects during the even semester. This can be seen through the resulting test scores in the initial test of learning with the highest score of 70 and the lowest score of 35 with an average value of 48 and a susceptible value of 35, in cycle I the value of quiz 1, the highest score of 72 and the lowest score of 40 with an average value 55 and susceptible to score 32 while cycle II, the highest score is 95 and the lowest score is 65 with an average value of 76 and a vulnerable value of 30. The conclusion of this study is that the use of youtube media can improve the understanding of PGSD students at STKIP Muhammadiyah OKU Timur on symmetry material.

Keywords :

Enhancement; Media; Symmetry; Youtube; Class Action.

PENDAHULUAN

Matematika merupakan suatu bahan kajian yang memiliki objek abstrak dan dibangun melalui proses penalaran deduktif, yaitu kebenaran suatu konsep diperoleh sebagai akibat logis dari kebenaran sebelumnya sehingga keterkaitan antar konsep dalam matematika bersifat sangat kuat dan jelas. Simetri merupakan salah satu konsep dasar dalam materi Geometri. Mahasiswa Pendidikan Guru Sekolah Dasar dipersiapkan untuk menjadi calon guru sekolah dasar yang handal dan professional, sehingga diwajibkan untuk menguasai kompetensi dasar pada setiap 


\section{$\pi$ (Phi)}

mata kuliah, termasuk mata kuliah geometri dan pengukuran. Geometri dan Pengukuran merupakan bagian dari ruang lingkup mata pelajaran matematika di sekolah dasar (Standar Isi, 2006).

Menurut Fitriasari (2019)

Kesalahan mahasiswa pada indikator adalah sebagian besar mahasiswa tidak memberikan penjelasan dari jawaban yang telah dituliskan. Selain itu terkait simetri putar, kesalahan yang umum dilakukan mahasiswa adalah tidak dapat memahami besaran sudut dalam melakukan simetri putar, dan tidak dapat menentukan sumbu simetri putar dengan benar. Menurut Yantoro (2019) Kemampuan awal mahasiswa dalam memahami konsep dasar dari bangun datar dan bangun ruang yang masih minim, hal ini ditunjukkan dari pengetahuan mereka tentang apa itu titik, garis hubungan titik dan garis, sudut serta simetri baik simetri sumbu maupun simetri putar. Oleh sebab itu perlu konsep pembelajaran yang tepat dan menarik untuk meningkatkan kemampuan dan pemahaman mahasiswa dalam memahami materi simetri. Salah satunya dengan pembuatan video yang dibuat dengan kosep demontrasi.

Heruman (2012) menyebutkan bahwa usia perkembangan siswa Sekolah Dasar (SD) masih terikat pada objek konkret yang dapat dengan mudah ditangkap oleh panca indranya. Menurut Soedjadi (2004) matematika sekolah adalah unsur-unsur atau bagian-bagian matematika yang dipilih atas dasar makna kependidikan yaitu untuk mengembangkan kemampuan dan kepribadian peserta didik, dan tuntutan perkembangan yang nyata dari lingkungan hidup yang senantiasa berkembangan seiring dengan kemajuan ilmu dan teknologi. Dalam Standar Isi mata pelajaran matematika disebutkan bahwa matematika merupakan ilmu universal yang mendasari perkembangan teknologi moderen, mempunyai peran
Jurnal Pendidikan Matematika Volume 5 Nomor 1 Tahun 2021

penting dalam berbagai disiplin dan memajukan daya pikir manusia. Perkembangan pesat di bidang teknologi informasi dan komunikasi saat ini dilatar belakangi oleh perkembangan matematika di bidang teori bilangan, aljabar, analisis, teori peluang dan matematika diskrit.

Menurut Sanjaya (2008) pemilihan media harus sesuai dengan tujuan yang ingin dicapai, kosep yang jelas, disesuaikan dengan karakteristik dan gaya belajar serta disesuaikan dengan kondisi lingkungan dan fasilitas yang tersedia. Untuk menguasai dan menciptakan teknologi di masa depan diperlukan penguasaan matematika yang kuat sejak dini (Standar Isi, 2006). Oleh sebab itu penggunaan teknologi yang tepat dan menarik sangat dibutuhkan untuk membantu siswa lebih mudah memahami materi pembelajaran, terkhusus pada masa pandemi saat ini dimana pembelajaran banyak dilakukan melalui online. Salah satu media online yang bisa digunakan diantaranya adalah youtube.

Tujuan penelitian ini untuk meningkatkan pemahaman mahasiswa PGSD di STKIP Muhammadiyah OKU Timur pada materi simetri melalui penggunakan media youtube.

Menurut (Kemdikbud, 2015) penelitian tindakan kelas adalah penelitian tindakan yang dilakukan oleh guru dengan tujuan memperbaiki mutu praktik pembelajaran di kelasnya". Penelitian tindakan kelas merupakan penelitian untuk memperbaiki dan meningkatkan kualitas pembelajaran. Hal ini sesuai dengan pendapat yang diungkapkan oleh (Bahri, 2012), penelitian tindakan kelas merupakan sebuah kegiatan yang dilaksanakan untuk mengamati kejadiankejadian dalam kelas untuk memperbaiki praktek dalam pembelajaran agar lebih berkualitas dalam proses sehingga hasil belajarpun menjadi lebih baik. Penelitian ini dilaksanakan dengan menggunakan 


\section{$\pi$ (Phi)}

rancangan PTK model Arikunto (2006) yang meliputi (1) Perencanaan, (2) pelaksanaan , (3) pengamatan dan (4) Refleksi. Hasil dari PTK ini diharapkan akan memberikan manfaat bagi siswa, guru dan sekolah terutama dalam pembelajaran Matematika. Adapun manfaat hasil penelitian ini yaitu, meningkatkan motivasi, sikap percaya diri dalam memberikan materi kepada siswa. Melatih kemampuan dalam menentukan konsep pembelajaran matematika simetri di kelas, bertanya jawab berdiskusi dalam kelompok dan menghargai pendapat orang lain. Meningkatkan kemampuan dalam memahami konsep dasar simetri pada mata kuliah Geometri dan Pengukuran.

\section{METODE PENELITIAN}

Penelitian Penelitian ini dilaksanakan di STKIP Muhammadiyah OKU Timur pada bulan April 2020. Subyek penelitian adalah mahasiswa PGSD angkatan pertama tahun 2019-2020 sebanyak 29 orang siswa, dan seorang dosen geometri dan pengukuran lain sebagai pengamat. Pengambilan data dilakukan dengan teknik tes dan non tes. Teknik tes meliputi pemberian soal pada awal sebelum pembelajaran, akhir siklus I dan akhir siklus II dan non tes meliputi observasi aktivitas mahasiswa pada saat pembuatan video youtube, Sebagai tolok ukur penelitian ini, apabila rata-rata nilai tes mahasiswa memiliki peningkatan dari siklus I ke siklus II. Prosedur Penelitian ini terdiri atas empat kegiatan yang dilakukan dalam siklus berulang. Empat kegiatan utama yang ada pada setiap siklus, yaitu 1). perencanaan, 2). Tindakan 3). pengamatan, 4). refleksi. (Arikunto, 2006:74).

\section{a. Proses Tindakan Siklus I Perencanaan.}

Dalam perencanaan yang perlu disiapkan meliputi: RPS, Bahan Ajar (Powerpoint), Instrumen penilaian. Pada tahap awal pembelajaran peneliti masih
Jurnal Pendidikan Matematika Volume 5 Nomor 1 Tahun 2021

menggunakan metode penjelasan yang sederhana.

\section{Pelaksanaan Tindakan.}

Pada tahap awal siswa diberi penjelasan singkat tentang materi simetri dalam bentuk PowerPoint yang diberikan melalui pembelajaran online dengan menggunakan media Whatsapp Grup (WAG). Pada kegiatan ini mahasiswa belum diberikan tugas untuk pembuatan video pembelajaran, mahasiswa hanya diminta untuk menanggapi dan bertanya materi yang diberikan.

\section{Observasi}

Observasi dilakukan bersamaan dengan tindakan, peneliti/pengamat, mengamati kecermatan dan aktifitas mahasiswa dalam memahami dan menanggapi materi simetri yang diberikan melalui WAG.

\section{Refleksi.}

Pada akhir siklus diadakan refleksi dengan cara pemberian tes tertulis pada mahasiswa dengan mengirimkan jawaban melalui email yang telah diberikan sebelunya dalam bentuk JPG atau PDF.

Hasil tes dan observasi aktifitas siswa dijadikan dasar perbaikan dan perubahan pada siklus II. Kekurangan pada siklus I diupayakan untuk diperbaiki dan hal-hal yang baik dipertahankan dan ditingkatkan pada siklus berikutnya.

\section{b. Proses Tindakan Siklus II Perencanaan}

Dalam perencanaan yang perlu disiapkan meliputi: RPS, Bahan Ajar (Powerpoint dan contoh video pembelajaran), Instrumen penilaian.

\section{Pelaksanaan Tindakan.}

Pada tahap awal mahasiswa diberi penjelasan singkat tentang tugas yang harus diselesaikan dengan cara diskusi kelompok yang terdiri 2 atau 3 anak dan mahasiswa diberikan satu buah contoh video pembelajaran yang dapat diakses lewat youtube dalam hal ini video yang digunakan adalah video yang dibuat oleh 
dosen

sendiri.

https://www.youtube.com/watch?v=-

JDnuahzKnM.

Pada kegiatan ini dengan menampilakan video pembelajaran yang telah dibuat sendiri oleh peneliti dalam hal ini dosen mata kuliah geometri dan pengukuran diharapkan mahasiswa mendapatkan gambaran komponen apa saja yang perlu disiapkan untuk membuat video pembelajaran. Selanjutnya proses mahasiswa diberikann tugas untuk membuat konsep video pembelajaran yang berkaitan dengan materi simetri dalam hal ini video yang buat harus menampilkan konsep dasar pemahaman materi simetri yang berdasarkan pembuktian dalam hal ini mahasiswa memperagakan metode

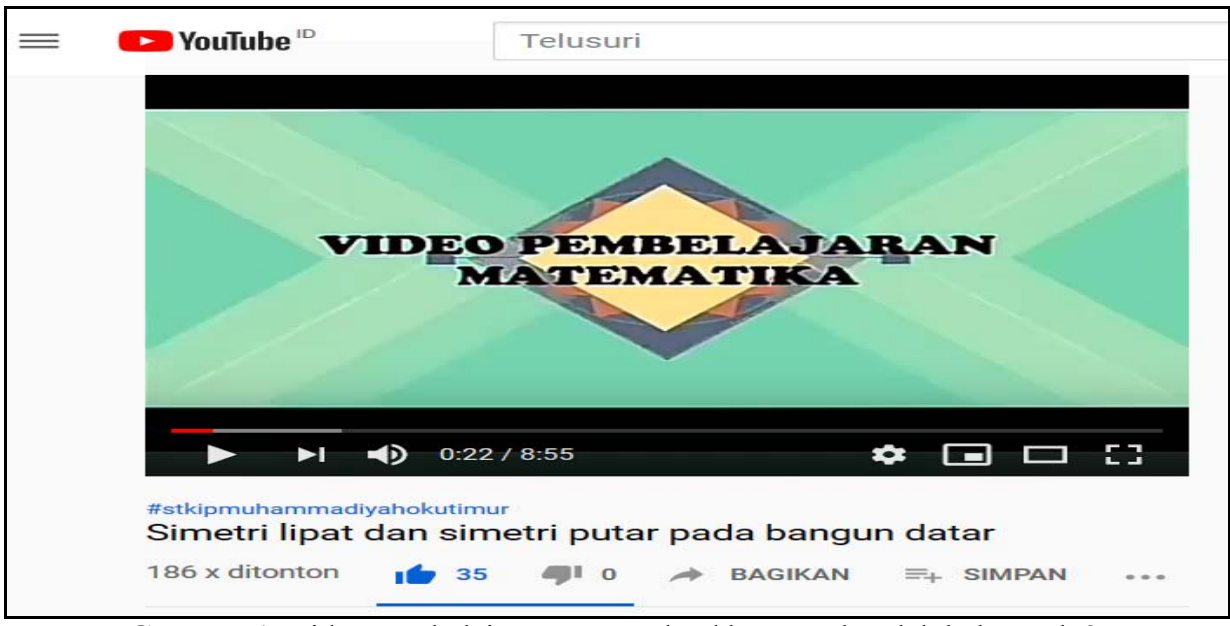

Gambar 1. Video pembelajaran yang upload ke youtube oleh kelompok 2.

\section{Refleksi.}

Pada akhir siklus diadakan refleksi dengan cara pemberian tes tertulis pada mahasiswa. Pada akhir siklus diadakan refleksi dengan cara pemberian tes tertulis pada mahasiswa dengan mengirimkan jawaban melalui email yang telah diberikan sebelumnya dalam bentuk JPG atau PDF. Hasil tes dan observasi aktifitas siswa dijadikan dasar pengolahan data.

\section{HASIL DAN PEMBAHASAN}

Pada kondisi awal hasil belajar yang rendah, minat dan motivasi mahasiswa dalam mengikuti pembelajaran materi simetri masih kurang, mahasiswa menganggap mudah materi simetri jadi terkesan menyepelekan, mahasiswa dapat menjawab pertanyaan tanpa dapat mengemukakan alasan jawabanya. Hal tersebut dijadikan tolak ukur untuk meningkatkan minat dan motivasi siswa sehingga didapatkan proses dan hasil 
pembelajaran yang lebih baik, khususnya pada Peningkatan pemahaman mahasiswa pada materi simetri.
Berikut tabel hasil tes awal, kuis 1 (refleksi siklus 1) dan kuis 2 (refleksi siklus 2).

Tabel 1. Hasil tes

\begin{tabular}{llccc}
\hline No & Uraian & $\begin{array}{c}\text { Tes Awal } \\
\text { (29 sample) }\end{array}$ & $\begin{array}{c}\text { Kuis 1 } \\
\text { (29 sample) }\end{array}$ & $\begin{array}{c}\text { Kuis 2 } \\
\text { (29 sample) }\end{array}$ \\
\hline $\mathbf{1}$ & Nilai terentah & 35 & 40 & 65 \\
$\mathbf{2}$ & Nilai tertinggi & 70 & 72 & 95 \\
$\mathbf{3}$ & Rata-rata nilai & 48 & 55 & 76 \\
$\mathbf{4}$ & Rentan nilai & 35 & 32 & 30 \\
\hline
\end{tabular}

Bila digambarkan dalam bentuk diagram blok (Chart) sebagai berikut

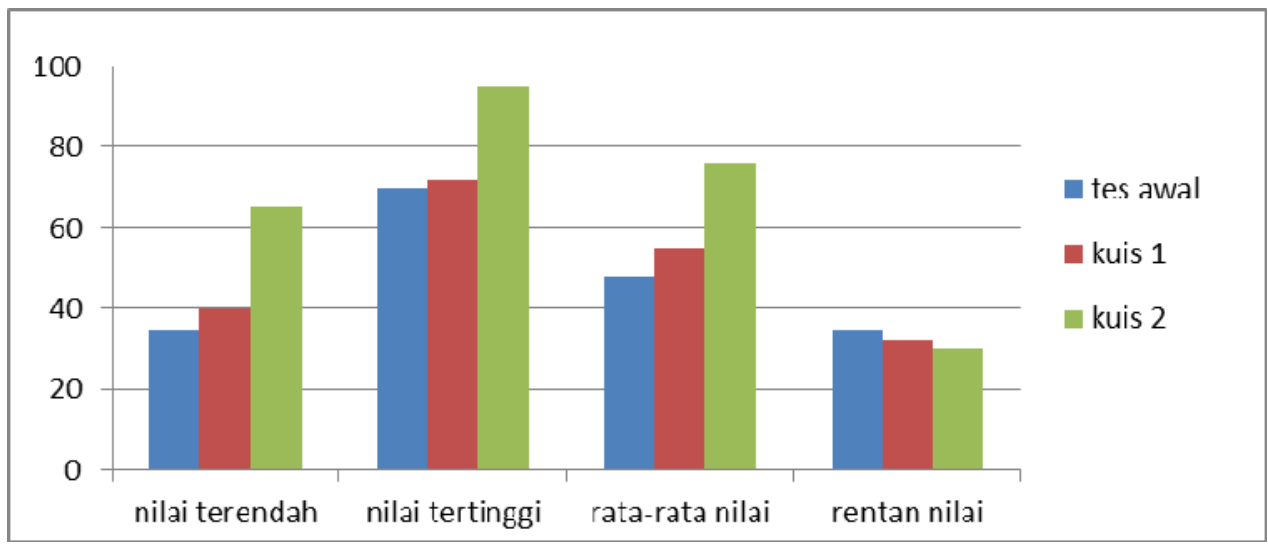

Gambar 2. Diagram Blok (Chart) Nilai tes mahasiswa

Dari tabel hasil tes awal, kuis 1 (refleksi siklus 1) dan kuis 2 (refleksi siklus 2). dan gambar diagram blok di atas dapat dilihat peningkatan hasil belajar mahasiswa pada materi simetri di Program studi pendidikan guru sekolah dasar di sekolah tinggi keguruan dan ilmu pendidikan Muhammadiyah OKU Timur terdapat peningkatan. Dapat dilihat dari hasil nilai kuis mahasiswa dimana adanya peningkatan dari nilai kuis 1 pada saat siklus 1 dan kuis 2 pada saat siklus ke 2 . Nilai tes yang dihasilkan pada tes awal pembelajaran nilai tertinggi 70 dan nilai terendah 35 dengan rata-rata nilai 48 dan rentan nilai 35 , pada siklus I nilai kuis 1 , nilai tertinggi 72 dan nilai terendah 40 dengan rata-rata nilai 55 dan rentan nilai 32 sedangkan siklus II, nilai tertinggi 95 dan nilai terendah 65 dengan rata-rata nilai 76 dan rentan nilai 30 .

\section{SIMPULAN DAN SARAN}

Berdasarkan hasil penelitian tindakan kelas dapat disimpulkan bahwa penggunakan media youtube untuk meningkatkan pemahaman mahasiswa PGSD di STKIP Muhammadiyah OKU Timur pada materi simetri. Dapat dilihat dari hasil nilai kuis mahasiswa dimana adanya peningkatan dari nilai kuis 1 pada saat siklus 1 dan kuis 2 pada saat siklus ke 2. Nilai tes yang dihasilkan pada tes awal pembelajaran nilai tertinggi 70 dan nilai terendah 35 dengan rata-rata nilai 48 dan rentan nilai 35 , pada siklus I nilai kuis 1 , nilai tertinggi 72 dan nilai terendah 40 dengan rata-rata nilai 55 dan rentan nilai 
32 sedangkan siklus II, nilai tertinggi 95 dan nilai terendah 65 dengan rata-rata nilai 76 dan rentan nilai 30. unja: $\quad$ https://onlinejournal.unja.ac.id/gentala/article/vie $\underline{\mathrm{w} / 6851}$

\section{DAFTAR PUSTAKA}

Arikunto, Suharsimi. (2006). Penelitian Tindakan Kelas. Jakarta : Bumi Aksara.

Bahri, Aliem. (2012). Penelitian Tindakan Kelas. Makassar : Universitas Muhammadiyah Makassar.

Badan Standar Nasional Pendidikan. (2006). Panduan Penyusunan Kurikulum Tingkat satuan Pendidikan Jenjang Pendidikan Dasar dan Menengah. Jakarta:BSNP. Jakarta. 2006

Fitrisari, P. (2019). Kemampuan Pemahaman Konsep Matematis Mahasiswa PGSD pada Materi Geometri Dasar. Dipetik pada tanggal 20 Maret 2020 dari jurnal PGRI : https://jurnal.univpgripalembang.ac.id/index.php/indiktika/art icle/view/3455

Heruman. (2012). Model Pembelajaran Matematika di Sekolah Dasar. Bandung: PT Remaja Rosda Karya.

Kemendikbud. (2015). Panduan Penilaian untuk Sekolah Dasar (SD). Jakarta: Kemendikbud

Soedjadi, R. (2004). "Pokok-Pokok Pikiran tentang Orientasi Masa Depan Matematika Sekolah di Indonesia." Media Pendidikan Matematika Nasional No.2 Tahun 1 hlm. 28-42. Surabaya: PPs IKIP Surabaya.

Sanjaya, W. (2008). Perencanaan dan desain Sistem Pembelajaran. Jakarta: Kencana Prenada Media Group.

Yantoro. (2019). Analisis Kesulitan Belajar Mahasiswa Pendidikan Guru Sekolah Dasar Pada Mata Kuliah Konsep Dasar Matematika Di Universitas Jambi. Dipetik pada tanggal 21 Maret 2020 dari Gentala 